\title{
Towards a greater understanding of the psychosocial impact of the symptoms of pituitary conditions
}

\section{Norman, Alyson}

http://hdl.handle.net/10026.1/16890

\subsection{8/bjcn.2021.26.5.236}

British Journal of Community Nursing

Mark Allen Healthcare

All content in PEARL is protected by copyright law. Author manuscripts are made available in accordance with publisher policies. Please cite only the published version using the details provided on the item record or document. In the absence of an open licence (e.g. Creative Commons), permissions for further reuse of content should be sought from the publisher or author. 


\section{British Journal of Community Nursing}

\section{Towards a greater understanding the psychosocial impact of the symptoms of pituitary conditions \\ --Manuscript Draft--}

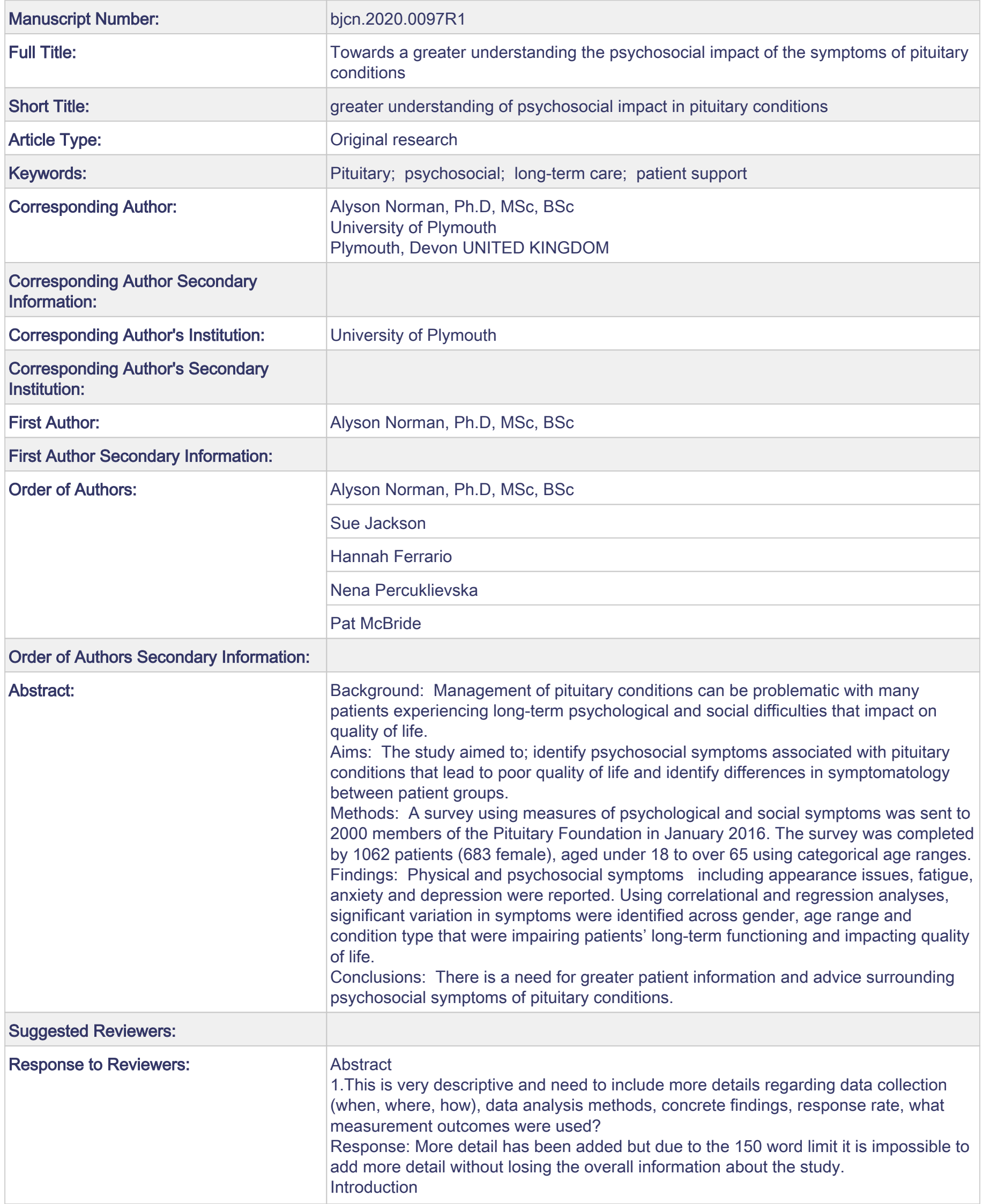


2.The first and second paragraph (page 1) need to be revised to describe accurately the pathophysiology of pituitary condition, prevalence, diagnosis and categorisation of pituitary conditions, citing relevant and up to date literature. A table summarising hormone, target glands and required replacement for acquired hypopituitarism would be useful here.

Response: More detail has been added as requested, and the additional references have been added to the reference list. A table has been added describing the various pituitary disorders, diagnostic testing, common symptoms, and information on treatments.

3.In page 2, the authors should elaborate and critically discuss why patients with pituitary conditions have impaired psychological well-being and QoL and support this with relevant evidence, such as the systematic review on QoL by Andela et al and Web et al.

Response: An additional paragraph has been added to page 2 outlining why pituitary conditions cause impaired QoL and how this is linked with psychological wellbeing.

4.More critical analysis is required on why this is an important research question and how did the authors formulate the study objectives: the "so what?" question.

Response: An additional sentence has been added to the bottom of page 2 outlining why it is important to understand the patient perspective on quality of life to inform psychological support services.

Methods

5.More details are required on the outcome measures, the objective of each measure, what did the previous study include and how did it guide the current one, did the questionnaire include and validated scales, how was the questionnaire developed, etc. Response: Information on the genesis of the current survey has been provided.

Table 1

6.I believe this is obsolete. The sections and outcome measures should be outlined in the "methods" section and the full questionnaire should be included in the on-line supplementary material.

Response: This has been removed as requested and the questionnaire added as supplementary material.

Results

7.The last paragraph in the "methods" needs to be moved in the results section and incorporated in Table 2 to avoid duplication. Number of participants should be noted with $\mathrm{N}$ or $\mathrm{n}$ for subgroups.

Response: This has been moved accordingly and the detailed content removed to avoid duplication with Table 2.

8.Start this section with an overall presentation of the results: what was the response rate, how many completed the survey in paper and how many on-line, how did you ensure there was no duplication of responses. Missing data - what was the percentage of missing data, how did you deal with this and did it affect the overall outcome of the results.

Response: The information about family data and the data of those undiagnosed has been integrated into the participant section of the method section, as has the information about pen and paper and online versions. The remainder of this detail, including justification for including these data is now incorporated within the opening paragraphs of the results section.

9.Please justify why did you decide to include family and undiagnosed patients' responses in the overall results. Did this provide a bias in responses?

Response: This has been included in the participant section of the results and in the results section a note has been made about the data not biasing the findings due to the small sample and that the family data was on behalf of the patients so family were purely enabling them to take part.

10. How did you measure quality of life and how did you define as "good quality of life"? This needs to be clarified.

Response: More information has been provided in the method section towards the end of the section on the generation of the questionnaire about the nine questions in the survey focussed on quality of life issues.

11.The tables need to be revised, adding number of participants in each response and overall number of participants.

Response: This has been changed accordingly.

12. Table 5 would be best represented in a chart. 


\begin{tabular}{|c|c|}
\hline & 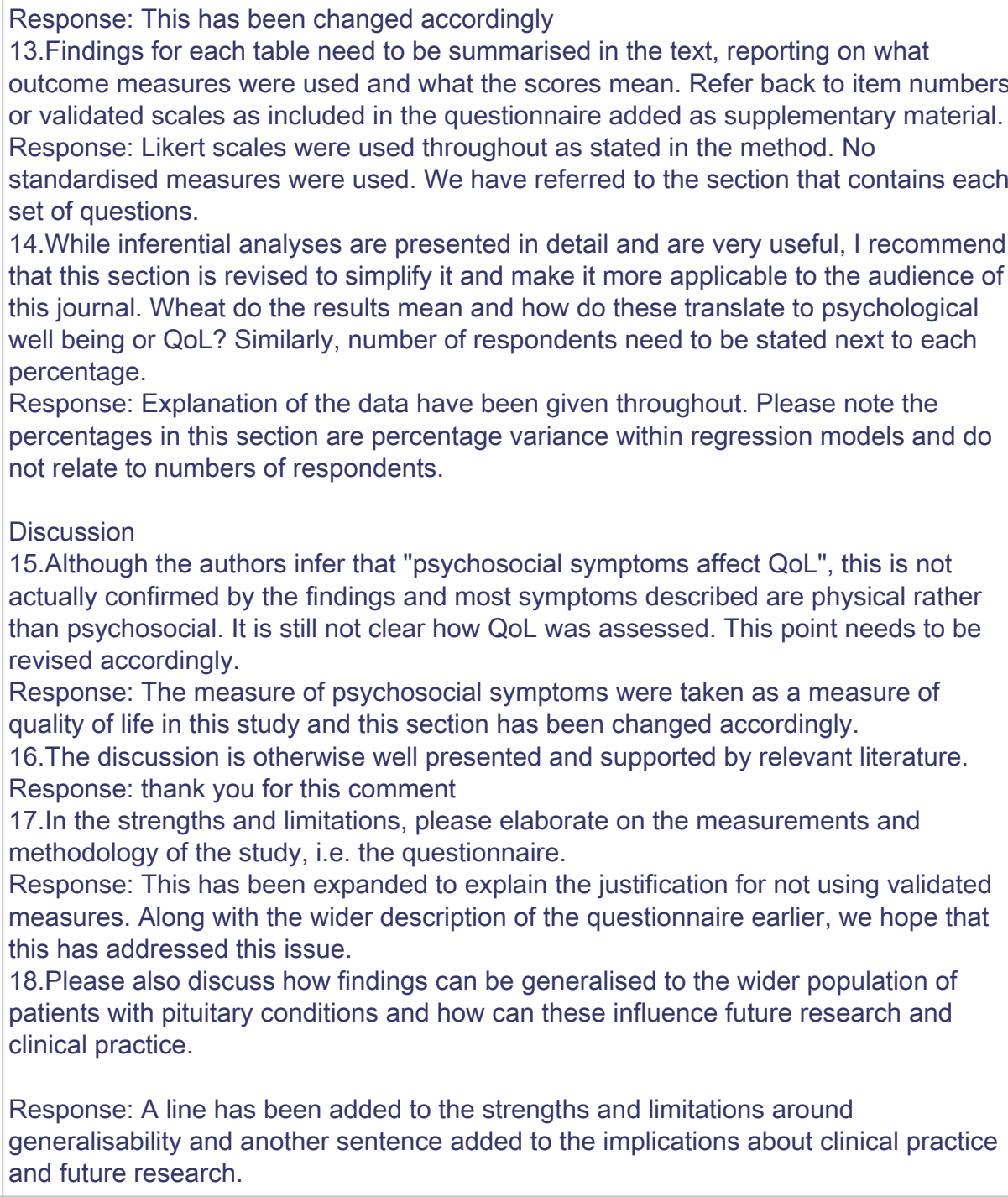 \\
\hline \multicolumn{2}{|l|}{ Additional Information: } \\
\hline Question & Response \\
\hline $\begin{array}{l}\text { Please enter the word count of your } \\
\text { manuscript, excluding references and } \\
\text { tables }\end{array}$ & 4271 \\
\hline
\end{tabular}




\section{Towards a greater understanding the psychosocial impact of the symptoms of pituitary conditions}

Dr Alyson Norman ${ }^{1}$, Dr Sue Jackson ${ }^{2}$, Hannah Ferrario ${ }^{1}$, Nena Percuklievska ${ }^{1}$, Pat McBride ${ }^{3}$

1: University of Plymouth, Plymouth, UK

2: University of the West of England, Bristol, UK

3: The Pituitary Foundation, Bristol, UK

Corresponding author: Dr Alyson Norman, alyson.norman@plymouth.ac.uk

ORCID codes: Dr Alyson Norman: 0000-0002-4332-6049

Acknowledgments: The authors would like to thank the participants of the pituitary foundation for taking part in this research. The authors confirm that no grant funding was obtained for the study. 


\section{Abstract}

Background: Management of pituitary conditions can be problematic with many patients experiencing long-term psychological and social difficulties that impact on quality of life.

Aims: The study aimed to; identify psychosocial symptoms associated with pituitary conditions that lead to poor quality of life and identify differences in symptomatology between patient groups.

Methods: A survey using measures of psychological and social symptoms was sent to 2000 members of the Pituitary Foundation in January 2016. The survey was completed by 1062 patients (683 female), aged under 18 to over 65 using categorical age ranges.

Findings: Physical and psychosocial symptoms including appearance issues, fatigue, anxiety and depression were reported. Using correlational and regression analyses, significant variation in symptoms were identified across gender, age range and condition type that were impairing patients' long-term functioning and impacting quality of life.

Conclusions: There is a need for greater patient information and advice surrounding psychosocial symptoms of pituitary conditions.

Keywords: Pituitary, psychosocial, long-term care, patient support

\section{$\underline{\text { Key points }}$}

1. Patients with pituitary conditions experience a range of psychosocial symptoms associated with their conditions that negatively impact quality of life.

2. These psychosocial symptoms are often overlooked by healthcare professionals

3. Patients reported a range of physical and psychosocial issues including mood swings, appearance issues, fatigue, anxiety and depression. 
4. Symptoms varied depending on age, gender, and condition type.

5. More advice and information are needed for patients from healthcare professionals to improve condition management.

\section{Reflective questions}

Please supply 3-5 questions based on your article that readers can use for reflective notes or discussion, which may be used to count towards their NMC revalidation.

1. How might health professionals support people with pituitary conditions to management their condition more effectively?

2. What role could community nurses play in providing information and support to patients with pituitary conditions?

3. How can community nurses link with charitable sector organisations to improve information and advice to patients? 


\section{Towards a greater understanding the psychosocial impact of the symptoms of pituitary conditions}

\section{Introduction}

As part of the hypothalamic-pituitary regulatory system, the pituitary gland plays an important role in maintaining endocrine homeostasis (Assa \& Ezzat 2013). It is particularly vulnerable to the development of benign non-cancerous tumours (adenomas) which can lead to an over or underproduction of any of the pituitary hormones (Levy 2004). Pituitary tumours are categorised based on their previously noted directional effects on hormone levels, with an additional category for the effects of tumour mass in the brain (primarily headaches and visual problems). In addition to tumours, genetic mutations can also result in isolated hormone deficiencies such as in congenital hypothyroidism (Assa \& Ezzat 2013). Occasionally traumatic brain injuries or treatments for other medical conditions can also lead to pituitary problems (Bondanelli et al. 2004). A wide range of pituitary disorders affect adults, some from birth while others develop over time (lorgi et al. 2012).

Classed as rare conditions, it is estimated that there are some $50,000-70,000$ pituitary patients in the UK (Pituitary Foundation 2016). Prolactinoma and clinically non-functioning pituitary adenomas are the two most prevalent pituitary adenomas, the latter reportedly found in up to $10 \%$ of MRI scans undertaken on the general population (Zada \& Carmichael 2019). There is a noted lack of epidemiological information on pituitary tumours; the latest review in the UK reported a rate of 77.6 per 100,000 head of population whilst also noting the significant variation between the various pituitary disorders recorded in their sample (from $57 \%$ for prolactinomas down to $2 \%$ for Cushings Disease) (Fernandez, Karavitaki \& Wass 2010). Table 1 
shows pituitary disorders along with their common symptoms and treatments. The management of pituitary conditions is challenging as patients with these conditions require life-long monitoring and complex drug treatment regimens (Levy 2004).

\section{INSERT TABLE 1 HERE}

While health professionals make clear distinctions between pituitary conditions, tumours, adenomas or pituitary status or functioning, anecdotally patients tend to talk about all these interchangeably as 'pituitary conditions'. Pituitary conditions can seriously affect day-to-day functioning, and patients can experience significant distress negatively impacting on psychosocial functioning and quality of life in ways that are often not sufficiently acknowledged or addressed by health professionals (Heald et al. 2004, Osbourne et al. 2006). Both the hormonal impact of pituitary conditions themselves, as well as the side effects of drug treatments can cause a range of both physical and psychological symptoms, such as changes in weight, mood swings and fatigue that can limit people's ability to function day-to-day (Andela et al, 2018). These factors are known to negatively influence quality of life through limiting people's ability to work, socialise and generally engage in daily living (Osbourne et al, 2006). The consequence of this impaired quality of life can be impaired psychological wellbeing, including manifestations of anxiety and depression (Andela et al, 2018). This is further exacerbated by the hormonal mood changes that pituitary conditions themselves can cause.

Sources of psychosocial support for patients with pituitary conditions is limited (Jackson et al. 2008), with the most comprehensive support being offered in the UK by the Pituitary Foundation (Underwood et al. 2019). This charitable organisation 
provides several services including support groups, telephone helplines and information leaflets for individuals with pituitary conditions.

For psychosocial support to be effective it helps to know which patients would benefit most or have the greatest need. There are multiple studies that have assessed the quality of life of patients with pituitary conditions using validated measures (Crespo et al, 2015; Lobatto et al. 2018). While this is the gold standard for research, it makes assumptions about what is meant by quality of life, a term which may be defined differently by patients, clinicians or researchers - something that is difficult to determine without talking to all groups. Without fully understanding how conditions impact on patients' day-to-day lives and how this affect quality of life, it is difficult to develop the appropriate support services to improve long-term psychological wellbeing.

The current study aimed to; firstly survey the psychosocial symptoms associated with pituitary conditions as identified by patients themselves in order to capture a patient perspective of how quality of life may be impaired and the psychological impact of this, and secondly, identify differences in symptomatology across patient groups to better understand the global versus condition-specific psychosocial issues in this patient group.

\section{Method}

Design \& Procedure: Respondents could complete either a pen and paper version or an electronic version on the survey platform "Survey Monkey". The survey design was based on material from a previous treatment satisfaction survey undertaken for the Pituitary Foundation (Jackson et al. 2008). The starting point for the 2008 treatment satisfaction survey was the qualitative analysis of free text answers 
provided by respondents to a previous needs analysis also undertaken for the Pituitary Foundation (Morris et al. 2006). These data identified four key themes (knowledge about the Pituitary Foundation, patient support needs, experiences of diagnosis, and the psychological impact of the pituitary conditions). Additionally specific items from a range of validated questionnaires were added to address the psychosocial elements, but no validated measures were included in their entirety. The resulting items were then used to create a survey structured as per the Big Cancer Information Survey (Cancerbackup 2016). For the latest survey, the 2008 survey had items added and amended by the staff at the Pituitary Foundation based on the information they needed from their current membership. As a result, participants were asked to provide feedback on various aspects of their pituitary care, including identifying the psychosocial symptoms they had experienced because of their condition. There was also a block of nine questions where participants could rate their satisfaction on a four-point Likert scale on issues likely to directly affect quality of life such as their ability to get around, sleep quality, selfsatisfaction and relationships with others (see supplementary information for a full version of the questionnaire).

The data were analysed using descriptive statistics as well as inferential statistics such as correlational analyses, t-tests and MANOVA which were used to identify differences in symptomatology across different pituitary conditions, age ranges and genders. Where appropriate regression models were employed to identify the variance in symptoms.

\section{Participants:}


Ethics approval was from the Faculty [University] ethics committee (10365532).

Participants were approached by the Pituitary Foundation and informed consent was obtained from all study participants.

The survey was sent out to 2,000 members of the UK Pituitary Foundation between June and August 2016. Participants were sent a link to an online survey or given the option to receive a pen and paper version of the questionnaire if they preferred. While the survey was targeted primarily at diagnosis pituitary patients, the invitation allowed family members or relatives to complete the questionnaire on behalf of their loved one where they did not feel capable of doing so (the questionnaire was long and could have caused considerable fatigue to some patients). These response data were treated as patient data on the grounds that the individuals had clearly stated that they were completing the questionnaire with the patient not from their own perspective. Additionally, individuals who considered themselves to have a pituitary condition but had not yet been formally diagnosed were included om the invitation list as many members may sign up to the Pituitary Foundation and may not have a diagnosis. Previous research has identified that that diagnoses can take many years (Underwood et al, 2019), so it was important to include the experiences of these individuals.

\section{Results}

One thousand and sixty-two individuals (53\% response rate) responded to the survey (683 female, 366 males, 13 undeclared), with most residing in England (861, 93\%). Of these responses, 567 were in pen and paper format and 495 were online. Participants ranged in age from under 18 to over 65 years of age - with categorical 
age ranges utilised in the survey, the modal age range was $36-55$ years. Of the responses, 1,004 were from patients with a pituitary condition either currently receiving treatment or in the post-acute treatment phase, 32 were relatives or friends answering on behalf of patients, eight had possible undiagnosed conditions. The remaining participants did not identify their status. The decision was taken to include these responses within the data set given the small number of responses compared to patient data. Participants reported a range of pituitary conditions (often declaring more than one). The full characteristics of the participants can be seen in Table 2.

\section{INSERT TABLE 2 HERE}

Response rates for individual sections and questions varied from $82.4 \%$ to $100 \%$ depending on the nature of the questions. Questions about psychosocial symptoms had higher response rates (87-100\%), while questions related to interaction with healthcare professionals and support were lower (82.4-89.5\%). All missing data were removed during analysis. Due to the high response rates overall, the presence of missing data is unlikely to have biased the findings. It is worth noting that questions nearer the end of the survey had a higher drop-out rate suggesting issues of fatigue played a part on missing data. This was considered in the questionnaire design, with questions on symptomology being placed near the beginning of the questionnaire.

Psychosocial symptoms \& quality of life: A range of psychosocial symptoms were reported (Figure 1), with the most common being fatigue $(769,72.5 \%)$, fluctuating moods $(617,58 \%)$, changes to appearance $(610,57.4 \%)$, and anxiety and depression (610, 57.4\%). Overall, 632 (59.5\%) respondents described their fatigue as "extreme", as did 336 (31.5\%) respondents who reported changes in their appearance. A further 424 (39.9\%) reported ongoing symptoms of anxiety and 
depression while 393 (37\%) reported mood swings. Likewise, 451 (42.5\%) participants reported experiences of prolonged pain or discomfort since their condition began with 234 (22\%) respondents reporting more chronic, ongoing pain. Just over a third of respondents $(382,36 \%)$ reported some issues with reduced fertility with $287(27 \%)$ reporting issues of infertility or impotence.

\section{Insert Figure 1 here}

While some respondents reported good quality of life in some domains using Likert scale measures as shown in section $E$ of the questionnaire (Table 3), others reported high levels of dissatisfaction. In these domains, a higher level of dissatisfaction is likely to lead to poorer quality of life. The most frequently reported quality of life issue was poor quality sleep (502 respondents, $47.2 \%$ ), a notable problem in a patient group reporting high levels of fatigue. This was closely followed by general dissatisfaction with oneself and one's life $(n=482,42.9 \%)$, poor sex life $(n=456,42.9 \%)$, lack of ability to get around $(241 ; 22.7 \%)$ and problems within personal relationships $(n=250,23.5 \%)$.

\section{INSERT TABLE 3 HERE}

Figure 1 shows that two other common quality of life issues were reduced social contact (463 participants, 43.6\%) and employment-related problems. For example, 434 respondents $(40.9 \%)$ stated that they had either had to reduce or stop their employment since the onset of their condition, with 305 respondents (28.7\%) stating that they had been forced to stop work entirely. A further 425 participants $(40 \%)$ identified as having had to stop or reduce education because of their condition. A more detailed analysis of the responses showed 423 (39.8\%) were in paid employment of 
some nature while 157 (14.8\%) were working in voluntary roles. Respondents generally reported a positive picture in relation to support available from employers and the attitudes in their workplace (Table 4), but many identified difficulties within the workplace alongside blighted career prospects $(n=411,38.7 \%)$. Within the sample, 408 respondents (38.4\%) felt unsupported by their organisation, $405(38.1 \%)$ felt unsupported by their manager and 458 (42.2\%) felt unsupported by their colleagues. A further 110 respondents (10.4\%) felt they had experienced discrimination due to their condition.

\section{INSERT TABLE 4 HERE}

The study also aimed to capture the support that pituitary patients were receiving in relation to quality of life issues. The data show that despite high levels of reduced social contact, many respondents felt that the emotional support they received from existing family, friends and relatives was satisfactory (Figure 2). Emotional support from healthcare professionals was more varied, with 425 respondents (40\%) being satisfied with the support they received, but $372(35 \%)$ reporting dissatisfaction. That said, close to three quarters of respondents (791 respondents, $74.5 \%$ ) agreed that they required more support while a further 193 respondents (18.2\%) identified a need for more information on self-management.

\section{INSERT FIGURE 2 HERE}

In relation to aspects of care, the two biggest issues were a lack of specialist endocrine services within easy travelling distance and poor diagnostic experiences. For example, 166 respondents (15.6\%) had to travel outside of their postcode area to attend a support group and a further $155(14.6 \%)$ had to travel out of region to 
attend an endocrine centre. As an example of diagnostic problems, 218 respondents (20.5\%) reported needing over 10 visits to their GP before receiving a diagnosis.

\section{Inferential analyses:}

A further aim of this study was to understand what support was available for patients who were experiencing quality of life issues because of their pituitary conditions and to identify any differences in quality of life across different pituitary conditions, age or gender.

Analysis of location data identified that there was a relationship between the distance from support groups and self-management, with respondents further from support groups reporting greater difficulties with self-management of their conditions $\left(r^{2}=-\right.$ $0.109, n=996, p=0.001)$. While being closer to support groups was associated with less fear after receiving a diagnosis of a pituitary condition $\left(r^{2}=0.081, n=996, p=\right.$ 0.01). This suggests that more local access to support services are needed to improve quality of life for patients.

To determine whether there were relationships between symptoms and specific characteristics, a series of stepwise regression analyses were conducted on age group, gender and each specific condition including all psychosocial symptoms reported. Some of the psychological and physical symptoms measured were generally universal, in that they seemed to affect all groups of patients regardless of their specific condition. These symptoms included fatigue, fluctuating mood, changes in appearance, anxiety, and depression. Condition-specific symptoms were reported that demonstrate higher levels of fatigue in patients with hypopituitarism $(\beta=0.274$, $p<0.01)$, increased changes in appearance in Cushing's disease $(\beta=0.103, p<0.01)$ 
and Acromegaly $(\beta=0.268, p<0.01$ ). These findings suggest that things symptoms are likely to lead to poorer quality of life in these patient groups.

A series of regression models identified key symptoms associated with each pituitary condition. For each model, the amount of variance explained (shown as percentages) represents symptoms and difficulties that were more likely to be reported in the specific patient group.

For non-functioning tumours, the only symptom category that explained significant variance was 'feeling generally unwell' concern, $\left(r^{2}(1,1041)=4.337, p=0.038\right)$. In craniopharyngioma, variance was best accounted for by appetite change (9.2\%), infertility (8.9\%) and weight gain $(6.8 \%)\left(r^{2}(3,1053)=11.265, p<0.001\right)$. Variance in hypopituitarism were explained by fatigue (20.6\%), poor illness recovery $(9.1 \%)$ and infertility $(18.4 \%)\left(r^{2}(3,1058)=48.911, p<0.001\right)$. Changes in appearance $(18.7 \%)$ and thin skin $(22.4 \%)$ explained the variance in symptoms among respondents with Cushing's disease $\left(r^{2}(2,1059)=61.907, p<0.001\right)$.

Prolactinoma was associated with headaches (15.1\%), inability to get around $(14.1 \%)$ and infertility $(9.7 \%)\left(r^{2}(3,921)=14.476, p<0.001\right)$. Diabetes insipidus symptoms were accounted for by changes in appetite $\left.r^{2}(1,679)=6.289, p=0.012\right)$, while Sheehan's syndrome was associated with pain $\left(r^{2}(1,679)=8.534, p=0.004\right)$. For those with Acromegaly, pain (7.7\%) and changes in appearance predominated $(23.7 \%)\left(r^{2}(2,870)=35.337, p<0.001\right)$. Finally, the variance in hypogonadism was mostly explained by impotence (19.2\%), reduced social contact (13\%) and low libido $(9 \%)\left(r^{2}(3,730),=20.716, p<0.001\right)$.

An initial correlational analysis highlighted that those who had completed treatment for their pituitary condition had more symptoms of fatigue than those in the early 
stages of treatment $\left(r^{2}=-0.095, n=928, p<0.005\right)$. No differences were found between those who had been diagnosed sooner rather than later. This demonstrates a potential long-term reduction in quality of life associated with fatigue after treatment has ended, highlighting that fatigue is not simply a symptom of the treatment process.

Some differences were reported across men and women. This is important for ensuring appropriate support is given to different patient groups. The regression model for gender identified that dizzy spells, headaches, weight gain, and poor sex life accounted for the largest amount of variance $\left(r^{2}(10,720)=26.086 p<0.001\right)$. A series of t-tests exploring gender differences highlighted that women were more likely to report dizzy spells $(\mathrm{t}(899)=5.234, \mathrm{p}<0.001)$, headaches $\left(\mathrm{t}_{(821)}\right)=4.314$, $\mathrm{p}<0.001)$ and weight gain $\left(\mathrm{t}_{(768)}=6.498, \mathrm{p}<0.001\right)$ whereas men were more likely to report poor sex life $\left(t_{(704)}=3.433, p=0.001\right)$. This shows differences in the symptoms that can lead to poor quality of life across men and women.

Differences were also found according to age. A further regression model identified differences in symptomatology according to age with infertility, impotence, dizzy spells, dissatisfaction with self generally, poor sex life, changes in appearance and pain explaining the largest variance $\left(r^{2}(9,811)=25.709, p<0.001\right)$. Younger respondents experienced more distress associated with changes in appearance $\left(F_{(5,815)}=15.039, p<0.001\right)$, infertility $\left(F_{(5,815)}=15.011, p<0.001\right)$, pain $\left(F_{(5,815)}=\right.$ 9.777, $\mathrm{P}<0.001)$, dizzy spells $\left(\mathrm{F}_{(5,815)}=6.509, \mathrm{p}<0.001\right)$ and poor quality of sex life $\left(F_{(5,815)}=2.858, p=.014\right)$. Older respondents reported impotence $\left(F_{(5,815)}=2.285\right.$, $\mathrm{p}=.045$ ) and feeling dissatisfied with themselves generally as potential causes of poor quality of life $\left(F_{(5,815)}=9.627, p<0.001\right)$. 


\section{Discussion}

Previous studies have highlighted the quality of life issues associated with pituitary conditions both in terms of generic symptoms (Baird et al. 2003), and those that are more condition-specific (Ascoli and Cavagnini 2006). The results from this study identified that patients experienced high levels of physical and psychosocial symptoms that are known to impact upon quality of life. These include physical symptoms such as fatigue and pain that can limit a person's ability to engage in daily life, psychological symptoms such as anxiety and depression which can lead to reduced contact with others and can cause distress, and finally social symptoms such as being unable to socialise or attend work. These factors together have an overall impact on quality of life. The greater the number of such symptoms, the more likely it is that quality of life will be impaired.

Some symptoms were found to be general such as fatigue, fluctuations in mood, appearance concerns, depression and anxiety. Additionally, there were some specific pituitary conditions with higher reported rates of other symptoms. These included; 'feeling generally unwell' amongst patients with non-functioning tumours, appetite change and weight gain in craniopharyngioma, infertility and poor illness recovery in hypopituitarism, and changes in appearance and thin skin in patients with Cushing's disease. Prolactinoma was associated with increased headaches and poor ability to get around. Patients with Sheenans' syndrome and acromegaly reported higher rates of pain, and those with diabetes insipidus complained of changes in appetite. These findings highlight that specific conditions bring with them susceptibilities to specific symptoms as well as a risk of more generic quality of life issues. As well as condition-specific symptoms, the study identified differences in symptoms reported by gender and age. 
Fatigue in particular has long been known to be a problem amongst those with pituitary conditions (Heald et al. 2004). So, it is maybe unsurprising that our survey identified $73 \%$ of respondents struggling with fatigue symptoms. This, along with the multitude of quality of life issues reported, indicates just how hard life is with a pituitary condition. This is further borne out by the data on employment where $29 \%$ of respondents surveyed had to give up work because of their condition adding a potentially not insignificant socioeconomic impact to the quality of life issues.

The impact of symptoms such as fatigue, appearance change, mood disturbance, anxiety and depression should not be underestimated. These generic symptoms can have an overwhelming influence on quality of life and are likely to be intrinsically linked. For example, fatigue can be described as a feeling of exhaustion that has physical, mental, and emotional components (McCabe 2009). This mental and emotional exhaustion is closely linked to the development of anxiety and depression (Brown and Kroenke 2009). Furthermore, changes in hormone levels can affect mood (Spencer et al. 2015) and may be exacerbated by dissatisfaction with appearance (Bessell et al. 2012) because of physiological changes further increasing anxiety and depression. Understanding how patients experience such psychosocial symptoms and reduced quality of life is of clinical importance to provide improved care and support.

While there is a breadth of literature on quality of life using standardised questionnaires (Andela et al. 2018; Lobatto et al. 2018) there has been less focus on understanding how patients themselves experience physical and psychosocial symptoms and what they consider to be poor quality of life. Previous studies using such standardised measures have identified similar issues to those in this study such as the generic symptoms of mood disturbance, fatigue and appearance changes 
(including weight gain) (De Bucy et al. 2017; Andela et al. 2018; Lobatto et al. 2018). By using patient-guided symptoms of quality of life, this study has highlighted some of the consequences of those symptoms such as reduced social contact, general feeling of ill-health and poor sex life. For example, issues such as impotence and infertility can be problematic for patients and affect their relationships with others as well as having a physical manifestation (Andela et al. 2017).

In this study over $35 \%$ of respondents expressed dissatisfaction with the support they received from healthcare professionals. This suggests that knowledge surrounding quality of life issues tends not to translate into meaningful support. As well as having an impact on quality of life, access to support services may be important for reducing the fear of diagnosis and for helping to improve selfmanagement (Dwarswaard et al. 2016). Whether this support is provided by healthcare professionals or through support groups, pituitary patients within the UK could benefit from increased sources of support.

As well as highlighting a degree of dissatisfaction with the emotional support received, the data in this study also captured the worryingly long time it takes many UK patients to receive a diagnosis. Within the present study a fifth of participants had to visit their GP at least 10 times before they receiving a diagnosis. This suggests a general lack of knowledge within community medicine about pituitary conditions. This lack of knowledge may be widespread and may help to explain why patients report feeling they receive inadequate emotional support surrounding the psychosocial aspects of their pituitary conditions (Jackson et al. 2008).

\section{Limitations}


Respondents were recruited through the UK Pituitary Foundation, therefore, the sample may not be representative of those with pituitary conditions more generally. It could be argued that members of the Pituitary Foundation are more likely to be receiving regular support through the organisation. This raises the question of whether those outside of the Pituitary Foundation may be experiencing greater quality of life issues. Conversely, it is possible that those who are experiencing more psychosocial symptoms are more likely to approach organisations like the Pituitary Foundation and may, therefore, present with greater quality of life issues. Future studies need to focus on recruiting a wider sample beyond users of third sector support organisations. Additionally, the sample was a self-selecting group with pituitary conditions and as such their status as patients could not be objectively verified through medical records. With these factors in mind, further investigation is needed to ensure that the results of this study can be generalised to a wider patient population. However, as symptoms identified by respondents are similar to previous studies with pituitary patients, the authors are confident that this represents quality of life factors that can be generalised across patient groups within the UK.

Other areas for improvement relate to the collection of the location data; the study asked only brief questions about the location of services across the UK. A more detailed investigation could provide more detailed information about the gaps and variations in service provision across the UK as it often varies (Underwood et al. 2019), as well as establishing clearer links between support services and quality of life.

Finally, as mentioned previously this study specifically did not use a validated measure of quality of life. It instead employed a patient-guided survey to understand how patients experience poor quality of life by measuring a range of physical, 
psychological and social symptoms of pituitary conditions that are known to be associated with poor quality of life. The justification for this was to gain a more global understanding of quality of life rather than a 'snapshot' of distress. This however, has implications for validity and reliability of the survey for research purposes.

\section{Implications}

These findings suggest that there is a need for more information and increased support for pituitary patients. While the use of support groups is important in helping to manage the distress of patients with long-term conditions and can improve condition management (Dwarswaard et al. 2016), it is crucial that individuals receive adequate support and information through healthcare providers at the point of diagnosis. Providing basic information and support at this stage may help to reduce the psychosocial impact of pituitary conditions on individuals, and in turn improve long-term quality of life (Aalto et al. 1997). Future clinical practice needs to ensure routine information and support services are available to support the unmet needs of this patient group, and future research should focus on evaluating improvements in quality of life resulting from such interventions.

\section{Conclusions}

The current study identified both generic quality of life issues associated with pituitary conditions relating to fatigue, appearance change and mood disturbance, including anxiety and depression, and more condition-specific symptoms including changes in appetite, infertility, weight gain, and poor illness recovery. The study emphasises the need for greater psychosocial support for those living with pituitary conditions in the UK to improve quality of life. 


\section{References}

Aalto AM, Uutela A, Aro AR. 1997. Health related quality of life among insulindependent diabetics: disease-related and psychosocial correlates. Patient educ couns. 30(3): 215-225.

Andela CD, Lobatto DJ, Pereira AM, van Furth WR, Biermasz NR. 2018. How non-functioning pituitary adenomas can affect health-related quality of life: a conceptual model and literature review. Pituitary. 21(2): 208-216.

Andela CD, Tiemensma J, Kaptein AA, Scharloo M, Pereira AM, Kamminga NG, Biermasz NR. 2017. The partner's perspective of the impact of pituitary disease: looking beyond the patient. J Health Psychol. 24(12): 1687-1697. Ascoli P, Cavagnini F. 2006. Hypopituitarism. Pituitary. 9(4): 335-342. Assa S L, Ezzat S. 2013. The Endocrine System. In ER Laws, S Ezzat, SL Asa, LM Rio, L Michel, R Knutzen (Eds) Pituitary Disorders. Chichester: John Wiley \& Sons.

Baird A, Sullivan T, Zafar S, Rock J. 2003. Quality of life in patients with pituitary tumors: a preliminary study. Qual Manag Health. 12(2): 97-105.

Bessell A, Dures E, Semple C, Jackson S. 2012. Addressing appearance-related distress across clinical conditions. Brit J Nurs. 21(19): 1138-1143.

Bondanelli M, Marinis LD, Ambrosio MR, Monesi M, Valle D, Zatelli, MC, Fusco A, Bianchi A, Farneti M, Degli Uberti ECI. 2004. Occurrence of pituitary dysfunction following traumatic brain injury. J Neurotraum. 21(6): 685-696. Brown LF, Kroenke K. 2009. Cancer-related fatigue and its associations with depression and anxiety: a systematic review. Psychosomatics. 50(5): 440-447. Cancerbackup 'Big Cancer Information Survey'. 2006. Available from: www.cancerbackup.org.uk. [Accessed $3^{\text {rd }}$ September 2006] 
Crespo I, Valassi E, Santos A, Webb SM. 2015. Health-related quality of life in pituitary diseases. Endocrin Metab Clin. 44(1): 61-70.

De Bucy C, Guignat L, Niati T, Bertherat J, Coste J. 2017. Health-related quality of life of patients with hypothalamic-pituitary-adrenal axis dysregulations: a cohort study. Eur J Endocrinol. 177(1): 1-8.

Dwarswaard J, Bakker EJ, van Staa A, Boeije HR. 2016. Self-management support from the perspective of patients with a chronic condition: a thematic synthesis of qualitative studies. Health Expect. 19(2): 194-208.

Fernandez A, Karavitaki N, Wass JAH. 2010. Prevalence of pituitary adenomas: A community-based cross-sectional study in Banbury (Oxfordshire, UK). Clin Endocrinol. 72(3): 377-382.

Heald AH, Ghosh S, Bray S, Gibson C, Anderson SG, Buckler H, Fowler HL. 2004. Long-term negative impact on quality of life in patients with successfully treated Cushing's disease. Clin Endocrinol. 61(4): 458-465.

lorgi ND, Allegri AEM, Napoli F, Bertelli E, Olivieri I, Rossi A, Maghnie M. 2012. The use of neuroimaging for assessing disorders of pituitary development. Clin Endocrinol. 76(2): 161-176.

Jackson S, Morris M, Ashley K. (2008). Joining the dots: devising a supported self-help strategy to help pituitary patients integrate their medical care. Int $\mathrm{J}$ Integr Care. 8: 4 .

Levy A. 2004. Pituitary disease: Presentation, diagnosis and management. J Neurol, Neurosur Ps. 75(S3): 47-52.

Lobatto DJ, Steffens AN, Najafabadi AHZ, Andela CD, Pereria AM, ven der Hout WB, Peul WC, Vliet TPM, Vlieland V, Biermasz NR, van Furth WR. 2018. Work 
disability and its determinants in patients with pituitary tumor-related disease. Pituitary. 21(6): 593-604.

McCabe M. 2009. Fatigue in children with long-term conditions: an evolutionary concept analysis. J Adv Nurs. 65(8): 1735-1745.

Morris M, Jackson S. 2006. Needs Analysis Report for Pituitary Foundation. Osbourne M, Jackson S, Morris M. 2006. Cinderella's story: the psychosocial impact of pituitary conditions. Endocrine Abstracts. 12: 84.

Pituitary Foundation. 2016. Pituitary Conditions | The Pituitary Foundation. Available from: https://www.pituitary.org.uk/information/pituitary-conditions/. [Accessed 18 ${ }^{\text {th }}$ March 2016].

Spencer SJ, Emmerzaal TL, Kozicz T, Andrews ZB. 2015. Ghrelin's role in the hypothalamic-pituitary-adrenal axis stress response: implications for mood disorders. Biol Psychiat. 78(1): 19-27.

Underwood A, Norman A, Jackson S. 2019. Pituitary conditions: Importance of geography and the Pituitary Foundation in patient support. Brit J Community Nurs. 24(9): 436-443.

Zada G \& Carmichael J. 2019. Pituitary adenoma. BMJ Best Practise. Available from: Pituitary adenoma - Symptoms, diagnosis and treatment | BMJ Best Practice. [Accessed $15^{\text {th }}$ February 2021] 
Table 1: Pituitary care survey sections

\begin{tabular}{|c|c|}
\hline Section & Description \\
\hline A: Demographics & Age, gender, ethnicity, geographic location \\
\hline B: Employment & $\begin{array}{l}\text { Occupation (former/current), education, } \\
\text { employer support }\end{array}$ \\
\hline C: Pituitary condition & Current stage, timescale of diagnosis, treatment \\
\hline D: Information & $\begin{array}{l}\text { Access, adequacy, timing, preferences } \\
\text { (presentation medium) }\end{array}$ \\
\hline E: Managing the condition & $\begin{array}{l}\text { Medication (prescription, new drugs), quality of } \\
\text { life issues (finance, practical and social support, } \\
\text { fatigue, appearance, moodiness etc) }\end{array}$ \\
\hline F: Membership of the Pituitary & $\begin{array}{l}\text { Use, preferences, awareness, satisfaction with } \\
\text { services offered and digital services }\end{array}$ \\
\hline & $\begin{array}{l}\text { How the foundation has helped, Issues } \\
\text { experienced by patient and how the Foundation } \\
\text { could help, the impact of pituitary conditions, } \\
\text { experiences of discussing pituitary condition } \\
\text { with others. And feedback on digital services } \\
\text { provided by the Pituitary Foundation. }\end{array}$ \\
\hline
\end{tabular}

Table 2: Participant characteristics

\begin{tabular}{|l|l|}
\hline Respondent characteristics & Number of Respondents \\
Gender & \\
Females & 683 \\
Males & 366 \\
Unspecified & 14 \\
Respondent Category & \\
Patient & 1004 \\
Family/Relative of patient & 32 \\
As yet undiagnosed & 8 \\
Other & 1 \\
& \\
Age ranges & \\
Under 18 years & 7 \\
18-25 years & 13 \\
$26-35$ years & 74 \\
$36-55$ years & 383 \\
$56-65$ years & 248 \\
Over 65 years & 330 \\
Unspecified & 8 \\
& \\
\hline
\end{tabular}




\begin{tabular}{|l|l|}
\hline Ethnicity & \\
White British & 948 \\
Black British & 8 \\
Other White & 67 \\
Other Black & 3 \\
Asian & 13 \\
Chinese & 3 \\
Other ethnic group & 9 \\
Unspecified & 13 \\
& \\
Geographic location (total sample) & \\
England & 861 \\
Scotland & 70 \\
Wales & 30 \\
Northern Ireland & 20 \\
Outside of the UK & 15 \\
Unspecified & 58 \\
Employment Status & \\
Full-time Employment & 282 \\
Part-time employment & 259 \\
Voluntary work & 157 \\
In education & 47 \\
& \\
Pituitary Condition & \\
Hypopituitarism & 193 \\
Diabetes insipidus & 183 \\
Non-functioning tumour & 170 \\
Acromegaly & 138 \\
Prolactinoma & 123 \\
Cushing's disease & 98 \\
Craniopharyngioma & 64 \\
Hypogonadism & 367 \\
Sheehan's syndrome & 14 \\
Time since diagnosis & \\
Less than three months & \\
3-6 months & \\
6-12 months & \\
1-2 years & \\
2-5 years & \\
5-10 years & \\
More than 10 years & \\
& \\
\hline
\end{tabular}


Table 3: Quality of life difficulties reported by respondents

\begin{tabular}{llllll}
\hline & \multicolumn{2}{c}{$\begin{array}{c}\text { Ability to } \\
\text { get around }\end{array}$} & $\begin{array}{c}\text { Quality of } \\
\text { Sleep }\end{array}$ & $\begin{array}{l}\text { Yourself } \\
\text { generally }\end{array}$ & $\begin{array}{l}\text { Sex life } \\
\text { relationships }\end{array}$ \\
\hline most dissatisfied & $7.6 \%$ & $16 \%$ & $21.6 \%$ & $6.4 \%$ & $11.6 \%$ \\
not satisfied & $15.1 \%$ & $31.2 \%$ & $21.3 \%$ & $17.1 \%$ & $33.8 \%$ \\
Satisfied & $32.3 \%$ & $29.4 \%$ & $19.6 \%$ & $40.6 \%$ & $31.9 \%$ \\
very satisfied & $31.1 \%$ & $11.1 \%$ & $4.3 \%$ & $18.2 \%$ & $9 \%$ \\
& & & & & \\
\hline
\end{tabular}

Table 4: Experiences of respondents in the workplace

\begin{tabular}{lllllll}
\hline & $\begin{array}{l}\text { Supported by } \\
\text { the } \\
\text { organisation }\end{array}$ & $\begin{array}{l}\text { Supported } \\
\text { by my } \\
\text { manager }\end{array}$ & $\begin{array}{l}\text { Supported } \\
\text { by my } \\
\text { colleagues }\end{array}$ & $\begin{array}{l}\text { Information } \\
\text { provision to } \\
\text { manage }\end{array}$ & $\begin{array}{l}\text { Discrimination } \\
\text { due to } \\
\text { condition }\end{array}$ & $\begin{array}{l}\text { Condition } \\
\text { reduced } \\
\text { career } \\
\text { prospects }\end{array}$ \\
\hline $\begin{array}{l}\text { Strongly } \\
\text { disagree }\end{array}$ & $6.5 \%$ & $6.7 \%$ & $3.5 \%$ & $13.9 \%$ & $22.2 \%$ & $11.6 \%$ \\
$\begin{array}{l}\text { Disagree } \\
\text { Agree }\end{array}$ & $10.8 \%$ & $8.7 \%$ & $8.8 \%$ & $16.7 \%$ & $17.2 \%$ & $10.5 \%$ \\
$\begin{array}{l}\text { Strongly } \\
\text { agree }\end{array}$ & $13.1 \%$ & $22.5 \%$ & $27.6 \%$ & $8.6 \%$ & $6.8 \%$ & $16.7 \%$ \\
\hline
\end{tabular}

Table 5: Emotional support from personal and professional sources

\begin{tabular}{lll}
\hline & $\begin{array}{l}\text { Emotional support from } \\
\text { friends or relatives }\end{array}$ & $\begin{array}{l}\text { Emotional support } \\
\text { from HCPs }\end{array}$ \\
\hline most dissatisfied & $5.1 \%$ & $8.3 \%$ \\
not satisfied & $14.7 \%$ & $27.1 \%$ \\
satisfied & $39.1 \%$ & $32.5 \%$ \\
very satisfied & $24.1 \%$ & $8 \%$ \\
\hline
\end{tabular}




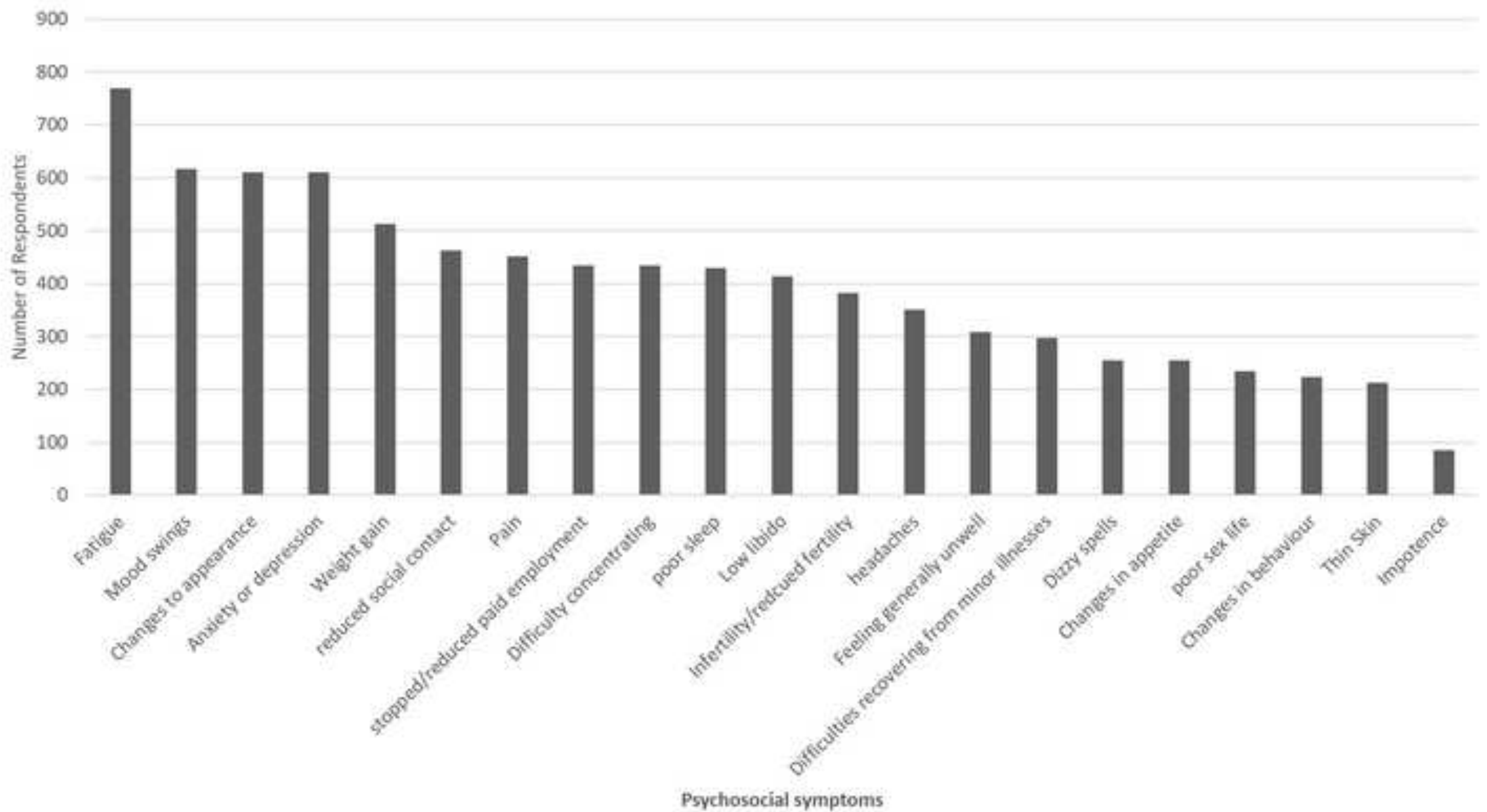




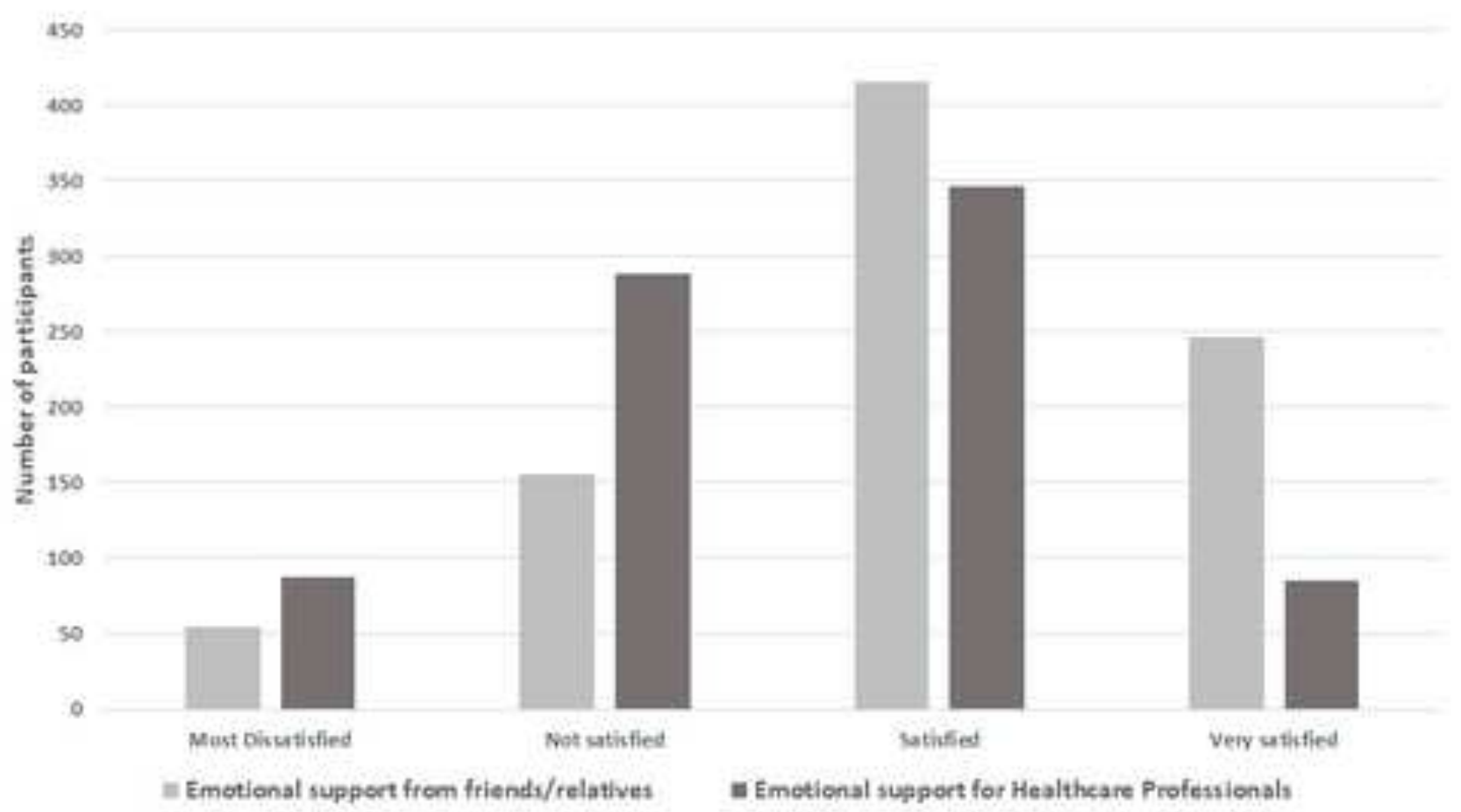

Figure 2: Emotional support from personal and professional sources $(N=1062)$ 
Table 1: Pathophysiology of pituitary conditions

\begin{tabular}{|c|c|c|c|}
\hline Pituitary disorder & $\begin{array}{l}\text { Diagnosis \& } \\
\text { testing }\end{array}$ & Symptoms & Treatment \\
\hline \multicolumn{4}{|l|}{ Secretory tumours } \\
\hline Prolactinoma & $\begin{array}{l}\text { Over-production of } \\
\text { prolactin } \\
\text { Hormone tests; } \\
\text { MRI scan; } \\
\text { Vision tests }\end{array}$ & $\begin{array}{l}\text { Headaches; visual } \\
\text { problems; osteoporosis } \\
\text { or bone loss } \\
\text { In women: changes in } \\
\text { menstruation; } \\
\text { production of breast } \\
\text { milk; vaginal dryness } \\
\text { In men: erectile } \\
\text { dysfunction; enlarged } \\
\text { breasts; decreased } \\
\text { face and body hair }\end{array}$ & $\begin{array}{l}\text { Dopamine agonists } \\
\text { to shrink tumour } \\
\text { and reduce } \\
\text { prolactin }\end{array}$ \\
\hline Acromegaly & $\begin{array}{l}\text { Over-production of } \\
\text { growth hormone } \\
\text { (GH) } \\
\text { Hormone tests (GH } \\
\text { \& IGF-1); glucose } \\
\text { tolerance test; } \\
\text { MRI scan; } \\
\text { CT scan }\end{array}$ & $\begin{array}{l}\text { Enlarged limbs and } \\
\text { facial features; } \\
\text { impaired vision; fatigue; } \\
\text { oily, coarse or } \\
\text { thickened skin; husky } \\
\text { voice; severe snoring }\end{array}$ & $\begin{array}{l}\text { Somatostatin } \\
\text { analogues to } \\
\text { maintain GH } \\
\text { levels; dopamine } \\
\text { agonists to reduce } \\
\text { GH and IGF-1 } \\
\text { levels; GH } \\
\text { antagonist to block } \\
\text { the effect of GH on } \\
\text { body tissues; } \\
\text { surgery to remove } \\
\text { tumour; } \\
\text { radiotherapy }\end{array}$ \\
\hline Cushings Disease & $\begin{array}{l}\text { Over-production of } \\
\text { ACTH } \\
\text { 24-hour urinary free } \\
\text { cortisol level test; } \\
\text { dexamethasone } \\
\text { suppression test; } \\
\text { CRH stimulation } \\
\text { test; } \\
\text { MRI scan; } \\
\text { CT scan }\end{array}$ & $\begin{array}{l}\text { Weight gain with round, } \\
\text { red face and extra fat } \\
\text { round neck; purple } \\
\text { stretch marks; high } \\
\text { blood pressure; } \\
\text { memory and } \\
\text { concentration } \\
\text { problems; fatigue; } \\
\text { osteoporosis; weak } \\
\text { muscles; irritability; } \\
\text { depression and mood } \\
\text { swings; poor immune } \\
\text { function; high blood } \\
\text { sugar } \\
\text { In women: irregular } \\
\text { menstruation }\end{array}$ & $\begin{array}{l}\text { Surgery to remove } \\
\text { tumour; } \\
\text { radiotherapy } \\
\text { Medication may be } \\
\text { needed to reduce } \\
\text { the effect of } \\
\text { cortisol on the } \\
\text { body }\end{array}$ \\
\hline \multicolumn{4}{|c|}{ Non-secretory pituitary disorders } \\
\hline $\begin{array}{l}\text { Non-functioning } \\
\text { adenoma }\end{array}$ & $\begin{array}{l}\text { Hypopituitarism } \\
\text { MRI scan; } \\
\text { Pituitary hormone } \\
\text { function test; } \\
\text { Vision tests }\end{array}$ & $\begin{array}{l}\text { Tumour mass effects: } \\
\text { headaches; visual } \\
\text { problems } \\
\text { Possible } \\
\text { hypopituitarism effects: } \\
\text { weight change; fatigue; } \\
\text { reduced libido; frequent }\end{array}$ & $\begin{array}{l}\text { None for micro- } \\
\text { adenoma }(<1 \mathrm{~cm}) \text {; } \\
\text { life-long monitoring } \\
\text { for macro- } \\
\text { adenoma }(>1 \mathrm{~cm}) \text {; } \\
\text { Surgery to remove } \\
\text { tumour }\end{array}$ \\
\hline
\end{tabular}




\begin{tabular}{|c|c|c|c|}
\hline & & $\begin{array}{l}\text { night-time urination; } \\
\text { joint pain; dizziness; } \\
\text { low blood pressure } \\
\text { In women: irregular } \\
\text { menstruation } \\
\frac{\text { In men: erectile }}{\text { dysfunction }}\end{array}$ & $\begin{array}{l}\text { Hormone } \\
\text { replacement may } \\
\text { be necessary to } \\
\text { correct any } \\
\text { hormone } \\
\text { imbalances }\end{array}$ \\
\hline $\begin{array}{l}\text { Craniopharyngioma } \\
\text { \& Rathke's cleft } \\
\text { cysts }\end{array}$ & $\begin{array}{l}\text { Various pituitary } \\
\text { effects } \\
\text { Vision tests; } \\
\text { CT scan; } \\
\text { Pituitary hormone } \\
\text { function test; } \\
\text { MRI scan; } \\
\text { In addition for } \\
\text { craniopharyrngioma: } \\
\text { Tumour biopsy; } \\
\text { tissue histology; }\end{array}$ & $\begin{array}{l}\text { Tumour mass effects: } \\
\text { headaches; visual } \\
\text { problems; } \\
\text { Interference with } \\
\text { pituitary effects: } \\
\text { constipation; nausea; } \\
\text { reduced libido; frequent } \\
\text { urination; excessive } \\
\text { thirst; obesity; body } \\
\text { temperature regulation } \\
\text { problems; fatigue \& } \\
\text { drowsiness; dry skin; } \\
\text { low blood pressure; } \\
\text { personality changes } \\
\text { In women: irregular } \\
\text { menstruation; } \\
\text { production of breast } \\
\text { milk } \\
\text { In children: lack of } \\
\text { growth; delayed } \\
\text { puberty }\end{array}$ & $\begin{array}{l}\text { Surgery to remove } \\
\text { tumour; } \\
\text { radiotherapy }\end{array}$ \\
\hline Hypopituitarism & $\begin{array}{l}\text { Various pituitary } \\
\text { effects e.g., GH } \\
\text { deficiency, } \\
\text { luteinizing hormone } \\
\text { (LH) and follicle- } \\
\text { stimulating hormone } \\
\text { (FSH) deficiency, } \\
\text { thyroid-stimulating } \\
\text { hormone (TSH) } \\
\text { deficiency, } \\
\text { adrenocorticotropic } \\
\text { hormone (ACTH) } \\
\text { deficiency, anti- } \\
\text { diuretic hormone } \\
\text { (ADH) deficiency, } \\
\text { prolactin deficiency } \\
\\
\text { Pituitary hormone } \\
\text { function tests }\end{array}$ & $\begin{array}{l}\text { GH deficiency: fatigue; } \\
\text { muscle weakness; } \\
\text { changes in body fat } \\
\text { composition; lack of } \\
\text { ambition; social } \\
\text { isolation } \\
\text { LH \& FSH deficiency: } \\
\text { reduced libido; } \\
\text { infertility; fatigue } \\
\text { In women: decreased } \\
\text { egg and estrogen } \\
\text { production from the } \\
\text { ovaries; hot flashes; } \\
\text { irregular menstruation; } \\
\text { In men: decreases } \\
\text { sperm and testosterone } \\
\text { production from the } \\
\text { testicles; erectile } \\
\text { dysfunction; decreased } \\
\text { face and body hair; } \\
\text { mood changes } \\
\text { In children: delayed } \\
\text { puberty } \\
\text { TSH deficiency: fatigue; } \\
\text { weight gain; dry skin; } \\
\text { constipation; feeling } \\
\text { cold }\end{array}$ & $\begin{array}{l}\text { Hormone } \\
\text { replacement such } \\
\text { as: } \\
\text { GH deficiency: } \\
\text { growth hormone } \\
\text { LH \& FSH } \\
\text { deficiency: } \\
\text { testosterone for } \\
\text { men; estrogen \& } \\
\text { progesterone for } \\
\text { women; } \\
\text { gonadatrophons } \\
\text { for infertility } \\
\text { TSH deficiency: } \\
\text { levothyroxin } \\
\text { ACTH deficiency: } \\
\text { corticosteroids to } \\
\text { replace adrenal } \\
\text { hormones } \\
\text { ADH deficiency: } \\
\text { desmopressin } \\
\text { acetate }\end{array}$ \\
\hline
\end{tabular}




\begin{tabular}{|c|c|c|c|}
\hline & & $\begin{array}{l}\text { ACTH deficiency: } \\
\text { severe fatigue; low } \\
\text { blood pressure, which } \\
\text { may lead to fainting; } \\
\text { frequent and prolonged } \\
\text { infections; nausea, } \\
\text { vomiting or abdominal } \\
\text { pain; confusion } \\
\text { ADH deficiency: can } \\
\text { cause diabetes } \\
\text { insipidus with } \\
\text { symptoms of excessive } \\
\text { urination; extreme } \\
\text { thirst; electrolyte } \\
\text { imbalances } \\
\text { prolactin deficiency: } \\
\text { In women: problems } \\
\text { with breast milk } \\
\text { production }\end{array}$ & \\
\hline Diabetes Insipidus & $\begin{array}{l}\text { Under-production of } \\
\text { vasopressin } \\
\text { water deprivation } \\
\text { test; } \\
\text { ADH hormone test; } \\
\text { Urine analysis; } \\
\text { MRI scan; } \\
\text { genetic test }\end{array}$ & $\begin{array}{l}\text { Excessive urination; } \\
\text { extreme thirst; } \\
\text { electrolyte imbalances; } \\
\text { problems sleeping; } \\
\text { fever; vomiting; } \\
\text { diarrhoea; weight loss }\end{array}$ & desmopressin \\
\hline
\end{tabular}


Table 2: Participant characteristics

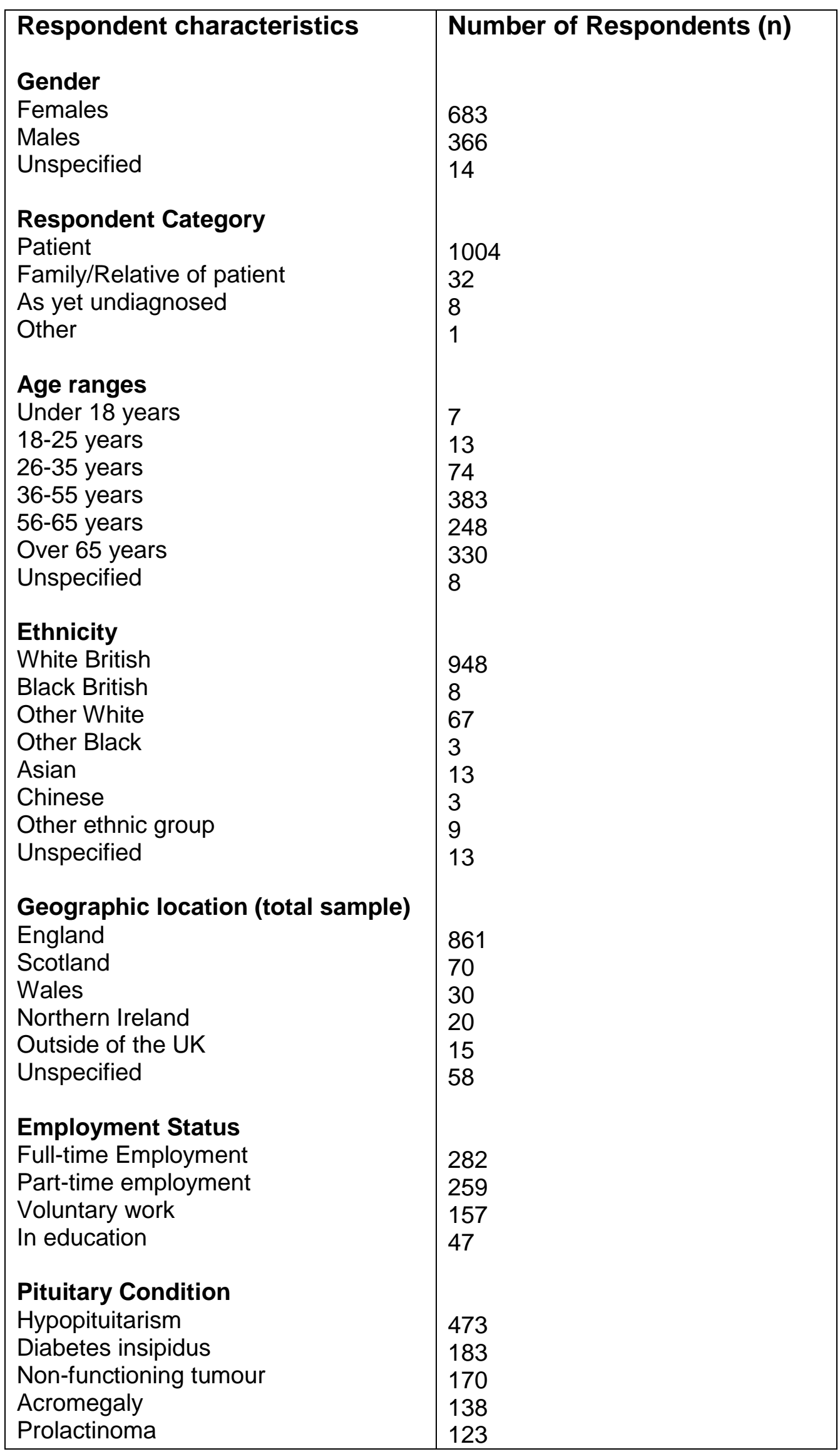




\begin{tabular}{|l|l|}
\hline Cushing's disease & 98 \\
Craniopharyngioma & 64 \\
Hypogonadism & 367 \\
Sheehan's syndrome & 14 \\
& \\
Time since diagnosis & \\
Less than three months & 15 \\
$3-6$ months & 22 \\
$6-12$ months & 32 \\
$1-2$ years & 51 \\
$2-5$ years & 122 \\
$5-10$ years & 193 \\
More than 10 years & 501 \\
& \\
\hline
\end{tabular}


Table 3: Quality of life difficulties reported by respondents

\begin{tabular}{llllll}
\hline & $\begin{array}{c}\text { Ability to } \\
\text { get around } \\
(\mathrm{n}=926)\end{array}$ & $\begin{array}{c}\text { Quality of } \\
\text { Sleep } \\
(\mathrm{n}=933)\end{array}$ & $\begin{array}{l}\text { Yourself } \\
\text { Generally } \\
(\mathrm{n}=919)\end{array}$ & $\begin{array}{l}\text { Sex life } \\
(\mathrm{n}=907)\end{array}$ & $\begin{array}{l}\text { Personal } \\
\text { Relationships } \\
(\mathrm{n}=917)\end{array}$ \\
\hline most dissatisfied & $81(7.6 \%)$ & $170(16 \%)$ & $123(11.6 \%)$ & $230(21.6 \%)$ & $68(6.4 \%)$ \\
not satisfied & $160(15.1 \%)$ & $332(31.2 \%)$ & $359(33.8 \%)$ & $226(21.3 \%)$ & $182(17.1 \%)$ \\
Satisfied & $343(32.3 \%)$ & $312(29.4 \%)$ & $339(31.9 \%)$ & $208(19.6 \%)$ & $432(40.6 \%)$ \\
very satisfied & $331(31.1 \%)$ & $118(11.1 \%)$ & $96(9 \%)$ & $46(4.3 \%)$ & $193(18.2 \%)$ \\
& & & & & \\
\hline
\end{tabular}


Table 4: Experiences of respondents in the workplace

\begin{tabular}{lllllll}
\hline & $\begin{array}{l}\text { Supported by } \\
\text { the organisation } \\
(\mathrm{n}=940)\end{array}$ & $\begin{array}{l}\text { Supported } \\
\text { by my } \\
\text { manager } \\
(\mathrm{n}=936)\end{array}$ & $\begin{array}{l}\text { Supported } \\
\text { by my } \\
\text { colleagues } \\
(\mathrm{n}=932)\end{array}$ & $\begin{array}{l}\text { Information } \\
\text { provision to } \\
\text { manage } \\
(\mathrm{n}=932)\end{array}$ & $\begin{array}{l}\text { Discrimination } \\
\text { due to } \\
\text { condition } \\
(\mathrm{n}=1062)\end{array}$ & $\begin{array}{l}\text { Condition } \\
\text { reduced career } \\
\text { prospects } \\
(\mathrm{n}=951)\end{array}$ \\
\hline $\begin{array}{l}\text { Strongly } \\
\text { disagree }\end{array}$ & $69(6.5 \%)$ & $71(6.7 \%)$ & $37(3.5 \%)$ & $148(13.9 \%)$ & $236(22.2 \%)$ & $123(11.6 \%)$ \\
$\begin{array}{l}\text { Disagree } \\
\text { Agree }\end{array}$ & $115(10.8 \%)$ & $92(8.7 \%)$ & $94(8.8 \%)$ & $177(16.7 \%)$ & $183(17.2 \%)$ & $112(10.5 \%)$ \\
$\begin{array}{l}\text { Strongly } \\
\text { agree }\end{array}$ & $141(13.3 \%)$ & $166(15.6 \%)$ & $155(14.6 \%)$ & $33(3.1 \%)$ & $38(3.6 \%)$ & $234(22 \%)$ \\
\hline
\end{tabular}


Click here to access/download Supporting audio or video files Survey Questions 11.3.2016 FINAL.pdf 